\title{
Reemerging of natural infection by Trypanosoma evansi in horses in Arari, Marajó Island, Brazil
}

\author{
Reemergência da infecção natural por Trypanosoma evansi em cavalos, \\ na região do Arari, Ilha do Marajó, Brazil
}

\author{
Josileide Araújo da Silva ${ }^{I}$ Tarcísio Oliveira Domiciano ${ }^{I}$ Daniele Pina Montão \\ Paulo Geovani Silva Sousa ${ }^{I}$ Leandro Lopes Ramos ${ }^{I}$ Laura Jamille Argolo Paredes ${ }^{\mathrm{I}}$ \\ Silvia Gonzalez Monteiro ${ }^{\text {II }}$ Gabriela Riet Correa Rivero ${ }^{\mathrm{I}}$ Alessandra Scofield ${ }^{\mathrm{I}}$ \\ Pedro Bezerra Júnior ${ }^{\mathrm{I}}$ Isis Abel Bezerra ${ }^{\mathrm{I}}$ Valíria Duarte Cerqueira $^{\mathrm{I}^{*}}$
}

\section{ABSTRACT}

Two outbreaks of trypanosomiasis by Trypanosoma evansi in horses in the municipality of Chaves, Marajó Island Pará State, Brazil are reported. The first outbreak occurred in April 2011 in a farm with 147 horses; of these, 47 (31.97\%) got sick, and 40 (27.21\%) died. The second outbreak occurred in May 2012 and involved nine properties. Of a total of 679 horses, 209 (30.07\%) got sick, and 183 (26.97\%) died. The main clinical signs observed in these horses were weight loss, abdominal edema, toe dragging, and pelvic muscle atrophy. Necropsy was performed in two horses, one from each outbreak. Macroscopic alterations were not seen in the horse from the first outbreak; however, the horse from the second outbreak exhibited emaciation, pallor and icterus, as well as enlarged spleen with prominent white pulp at cut surface. Histopathology of the central nervous system of both animals revealed mild to severe, diffuse lymphoplasmacytic encephalitis, with presence of Mott cells. Immunohistochemistry for T. evansi revealed structures similar to intralesional trypomastigote forms. Between November and December of 2013, an epidemiological survey was carried out in the municipalities of Cachoeira do Arari. Santa Cruz do Arari, Salvaterra, Soure, and Chaves. Only Santa Cruz do Arari and Chaves had reported cases of the disease. Blood samples were collected from 243 horses for detection of T. evansi $D N A$ by polymerase chain reaction $(P C R)$ and 20 were positive.

Key words: equids, trypanosomiasis, Pará, Marajó Island.

RESUMO

São relatados dois surtos de tripanossomiase por Trypanosoma evansi, em cavalos no municipio de Chaves, Ilha do Marajó, Pará, Brasil. O primeiro surto ocorreu em abril de 2011 em uma fazenda com 147 cavalos, em que 47 (31,97\%) adoeceram e $40(27,21 \%)$ morreram. O segundo ocorreu em maio de 2012 e envolveu nove propriedades. De um total de 679 cavalos, 209 (30,07\%) adoeceram e 183 (26,97\%) morreram. Os principais sinais clínicos observados foram perda de peso, edema abdominal, emboletamento dos membros e atrofia da musculatura da região pélvica e membros posteriores. A necropsia foi realizada em dois cavalos, um de cada surto. $O$ equino do primeiro surto não apresentou lesões macroscópicas, enquanto o segundo, do segundo surto, apresentava emagrecimento, palidez e icterícia, aumento do baço com protrusão da polpa branca ao corte. O sistema nervoso central de ambos os animais revelou uma leve à severa encefalite linfoplasmocitária, difusa, com presença de células de Mott. A imunohistoquímica para $\mathbf{T}$. evansi revelou estruturas similares a formas tripomastigotas nas lesões. Entre novembro e dezembro de 2013, um levantamento epidemiológico foi realizado nos municípios de Cachoeira do Arari, Santa Cruz do Arari, Salvaterra, Soure e Chaves. Somente Santa Cruz do Arari e Chaves relataram casos da doença. Foram coletadas amostras de sangue de 243 equinos e realizada a reação em cadeia de polimerase (PCR) para a detecção do DNA de T. evansi das quais 20 foram positivas.

Palavras-chave: equídeos, tripanossomíase, Pará, Ilha de Marajó.

\section{INTRODUCTION}

Trypanosoma evansi is the etiological agent of an important trypanosomiasis popularly known in Brazil as "surra", "derrengadera" or "mal das cadeiras" (SILVA et al., 2002) which are all popular terms that refer to a problem on the hind limbs and hips. The disease caused by this protozoan affects various domestic and wild mammals, like equines, bovines, buffaloes, dogs,

\footnotetext{
IPrograma de Pós-graduação em Saúde Animal da Amazônia, Faculdade de Veterinária, Universidade Federal do Pará (UFPA), Avenida dos Universitários, s/n, Bairro Jaderlândia, 68746-360, Castanhal, PA, Brasil. E-mail: valiria@ufpa.br. "Corresponding author.

IIDepartamento de Microbiologia e Parasitologia, Centro de Ciência da Saúde (CCS), Universidade Federal de Santa Maria (UFSM), Santa Maria, RS, Brasil. 
rabbits, armadillo, coati and capybaras (SILVA et al., 2002; HERRERA et al., 2004).

T. evansi is present in nearly all continents, American, Asian, Oceania, African and European (REID, S., 2002; SILVA et al., 2002) and is endemic in Africa (ABEER \& SHAYMAN, 2011). South America also has areas considered enzootic for this parasite, such as the Pantanal area, Brazil (HERRERA et al., 2004).

The transmission of $\boldsymbol{T}$. evansi occurs through blood-sucking vectors, especially tabanids and flies of the genus Stomoxys, hematophagous bats (Desmodus rotundus), and, probably, ticks and leaches (CAMARGO et al., 2004; CARREIRA, 2005). In South America, wild animals, especially capybaras (Hidrochoerus hidrochaeris) and ring-tailed coatis (Nasua nasua), are considered important T. evansi reservoirs. Capybaras are often implicated as the source of infection in horses during outbreaks (RODRIGUES et al., 2005; RODRIGUES et al., 2009).

Studies have shown an apparent resurgence of infections by $\boldsymbol{T}$. evansi in horses in Brazil, with reports in the Midwest, South, and North regions of the country. In the state of Pará, the last report of the disease in horses dates to 1941, in Marajó Island (JANSEN, 1941). The aim of this study was to describe clinical and pathological aspects of natural infection by $\boldsymbol{T}$. evansi in horses in the municipality of Chaves, as well as to investigate its prevalence in municipalities of the micro region of Arari, Marajó Island, Pará State, Brazil.

\section{MATERIALS AND METHODS}

Two outbreaks of equine trypanosomiasis that occurred in April 2011 and May 2012 in the municipality of Chaves, state of Pará, Brazil, were investigated. In the first outbreak, a 30-monthold horse, which had exhibited neurological signs, was subjected to necropsy by veterinarians of the Agricultural and Livestock Defense Agency of the state of Pará (ADEPARÁ). Only parts of the brain were fixed in formalin and submitted to the Laboratory of Animal Pathology of the Federal University of Pará for histopathology examination. Clinical and epidemiological data were collected by the technicians of ADEPARÁ and submitted to the laboratory along with the biological samples. In the second outbreak, clinical, pathological, and epidemiological data were obtained through visits to nine properties where the disease was occurring. In the first outbreak, of a total of 147 horses, 47 got sick and 40 died. In the second outbreak, of a total of 679 horses, 209 got sick, and 183 died.

During the visits, clinical examinations of sick animals were performed; blood samples were collected from 57 animals for parasitological examination and detection of T. evansi DNA by PCR. Necropsy was performed in one horse, an adult with approximately six years old that died during the visit. Tissue fragments from all organs of the abdomen, thorax, and central nervous system (CNS) were collected and fixed in $10 \%$ buffered formalin.

Fragments were routinely processed for histopathological examination, and stained with hematoxylin and eosin. Paraffin-embedded fragments of the CNS were submitted to the Prairie Diagnostic Service, Western College of Veterinary Medicine, University of Saskatchewan, Canada, for immunohistochemical detection of T. evansi.

Between November and December of 2013, visits were made to rural properties of the municipalities of Chaves, Santa Cruz do Arari, Cachoeira do Arari, Salvaterra and Soure, which belong to the micro region of Arari, to collect blood samples from the horses in order to perform an epidemiological survey (Figure 1).

Blood samples were collected randomly, independent of sex or breed. Stratified sampling was conducted using the municipalities as strata. Sample size was calculated with the statcalc tool in Epiinfo ${ }^{\mathrm{TM}}$ 7.1.2. software using an expected frequency of $20 \%$, absolute error of $5 \%$, and confidence interval of $95 \%$.

The number of samples obtained were 75 from the municipality of Soure, 24 from Santa Cruz do Arari, 12 from Cachoeira do Arari, and 5 from Salvaterra. For the municipality of Chaves, were considered the 57 samples collected during the second outbreak, in the properties which had sick animals and/or history of the disease, and the other 70 , were collected from farms where there was only the history of the disease earlier. Thus, in Chaves, were collected 127 samples.

DNA extraction from the blood samples was performed using Illustra ${ }^{\mathrm{TM}}$ Blood Genomic Prep Mini Spin Kit (GE Healthcare) following the manufacturer's instructions. All DNA samples were kept in DNase-free, sterile tubes, which were labeled and stored at $-20^{\circ} \mathrm{C}$ for molecular analysis. DNA preparations were subjected to PCR for specific detection of $\boldsymbol{T}$. evansi as described by CLAES et al. (2004), with modifications. The primers used, ROTAT 1.2 forward (GCGGGGTGTTTAAAGCAATA) and ROTAT 

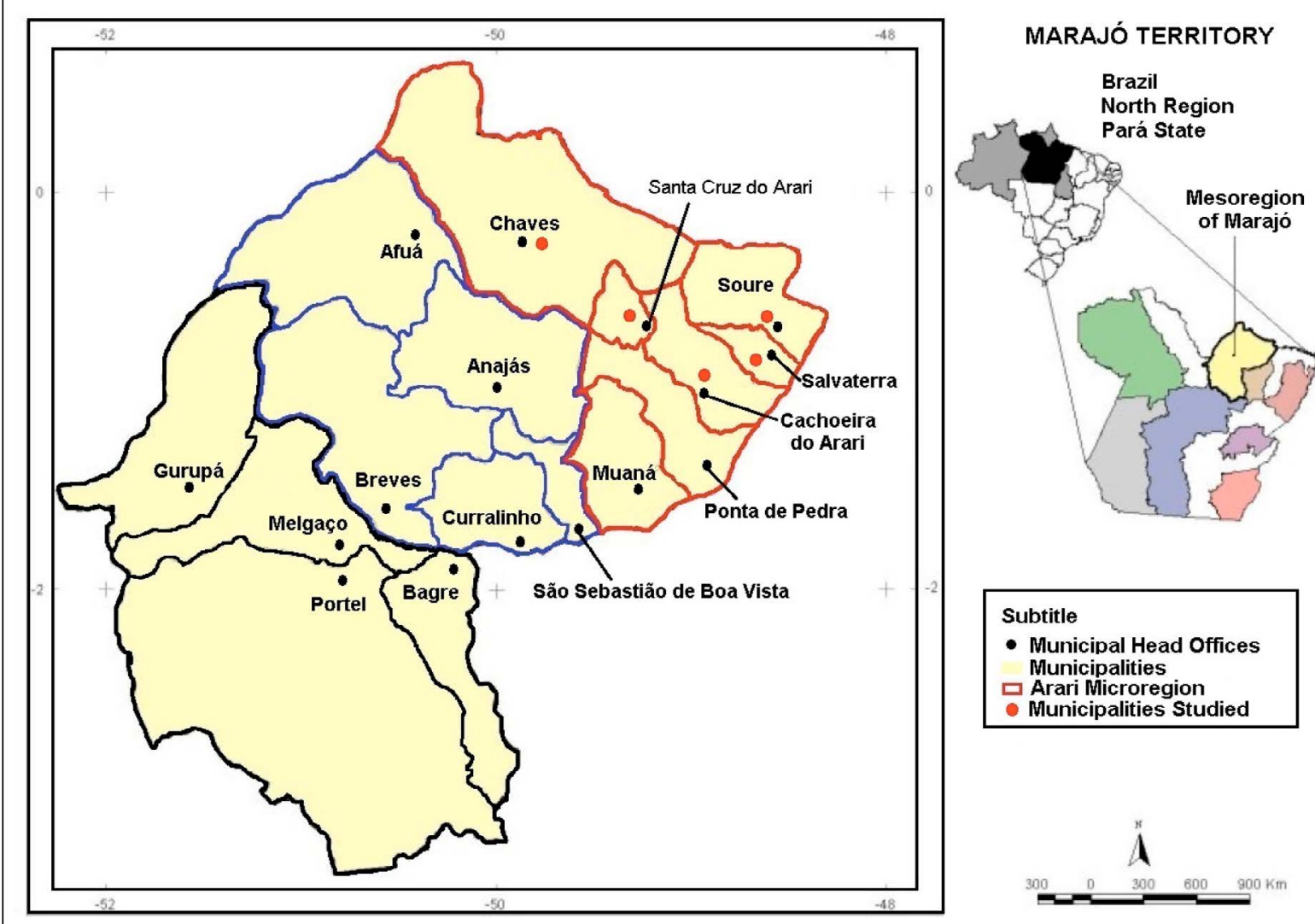

Figure 1 - Location map of the Microregion of Arari, with the municipalities studied.

1.2 reverse (ATTAGTGCTGCGTGTGTTCG), were specific for T. evansi and yielded a $205 \mathrm{bp}$ product. Negative and positive controls were used in all reactions. The positive control used was DNA extracted from the blood of an animal experimentally infected with $\boldsymbol{T}$. evansi, which belonged to the Veterinary Parasitology Laboratory at Universidade Federal de Santa Maria, in Rio Grande do Sul State, Brazil. The negative control used was DNA extracted from the blood of a healthy foal negative for infection by $\boldsymbol{T}$. evansi as assessed by PCR and blood smear analysis. Each reaction also contained a contamination control with the PCR master mix and double distilled water instead of the test DNA. Products obtained by PCR were stained with ethidium bromide $\left(0.5 \mu \mathrm{g} \mathrm{mL}^{-1}\right)$ and subjected to electrophoresis in $1.5 \%$ agarose gels. A $50 \mathrm{bp}$ molecular weight ladder (Ludwig Biotec ${ }^{\circledR}$ ) was used to estimate the size of the amplified DNA fragments. A UV transilluminator (Quantum ST41000/26M) with a computer photodocumentation system was used to visualize electrophoresis products.

\section{RESULTS}

The main clinical signs of affected horses from all farms were weight loss, subcutaneous edema of the ventral abdominal region, stiff and staggering gait, pelvic muscle atrophy, pale or yellow (icteric) mucous membranes, toe dragging, muscle weakness, incoordination, and frequent falls. At necropsy, the horse of the first outbreak exhibited edema of the ventral abdominal region, with $2-3 \mathrm{~cm}$ at the cut surface of subcutaneous and edema of the limbs. The horse of the second outbreak exhibited pallor of mucous membranes and enlarged spleen; the spleen cut surface revealed protrusion of the white pulp.

Histopathology of the brain of the necropsied horse from the first outbreak revealed a diffuse, mild to severe, lymphoplasmacytic encephalitis affecting both white and grey matter (Figure 2A). Some plasma cells were swollen and contained numerous cytoplasmic hyaline inclusion bodies (Russell bodies) displacing the nucleus even more toward the periphery (Mott cells) (Figure 2B). 


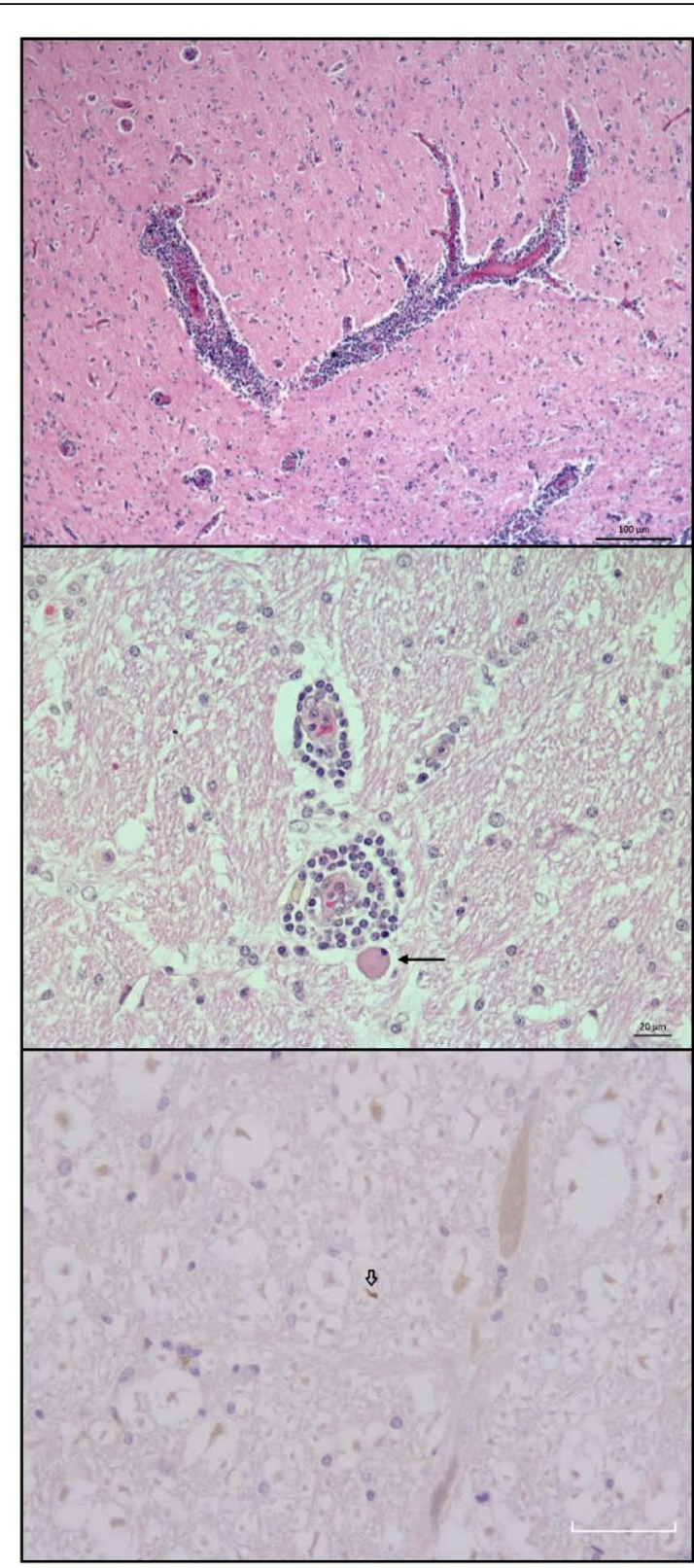

Figure 2 - A. Horse. First outbreak. CNS. Thalamus. Diffuse to moderate mononuclear perivascular infiltrate with mild multifocal gliosis. H.E., Magnification: 10x". B. Mild perivascular infiltrate containing swollen plasma cell and lymphocytes with cytoplasmic hyaline inclusion bodies (Russell bodies) displacing the nuclei to the periphery (Mott cells) (arrows) H.E., Magnification: 400x". C. Second outbreak. CNS. Brain cortex. Immunostaining of structures that resemble free trypomastigote forms in the neuropil (wide arrows). Immunohistochemistry, anti-T.evansi antibody, streptavidin-biotin-peroxidase technique, hematoxylin counterstain. Magnification: 400x.
Furthermore, mild to moderate endothelial swelling was seen; the perivascular neuropil was vacuolated and contained astrocytes with swollen nuclei and evident eosinophilic cytoplasm. These neurological lesions were also observed in the brain and spinal cord of the necropsied horse from the second outbreak. This horse also exhibited diffuse, moderate to severe hemosiderosis of spleen, liver, lymph nodes, lungs, and lamina propria and submucosal layer of the intestines. There was moderate lymphoid hyperplasia of the white pulp in the spleen, lymph nodes, Peyer's patches, and lymphoid clusters of the large intestine. Lymphoid clusters of the large intestine also exhibited rare Mott cells. The liver exhibited diffuse, moderate hepatocyte vacuolation. From the first necropsied horse, only central nervous system was forwarded to the Laboratory by the State Defense Agency.

Immunohistochemical evaluation of the nervous system with an anti-T.evansi antibody revealed rounded or elongated structures, the latter resembling free trypomastigote forms in the neuropil in both equines (Figure 2C). T. evansi DNA was detected by PCR in 14 samples from the municipality of Chaves, and in six samples from the municipality of Santa Cruz do Arari (Table 1).

\section{DISCUSSION}

A higher frequency of cases occurred in the end of the rainy season, probably owing to a larger vector population during this period. The rainy season in Marajó Island is between January and June, which is also the period with higher density of hematophagous insects, which reach their highest population numbers in the end of July, when the drought period begins (JANSEN, 1941). Several dipterous genera have been considered to be $\boldsymbol{T}$. evansi vectors (SILVA et al., 2002).

In addition, the farm owners in this study reported occurrence of a large amount of leaches during the rainy season, which could increase the risk of T. evansi transmission since these worms could be vectors and reservoirs of this protozoan (CAMARGO, 2004). Presence of wild reservoirs, such as capybaras and coatis, is frequently reported by locals from the properties visited during this study. Capybaras are considered important T. evansi reservoirs (HERRERA et al., 2004) and have been considered to be infection sources during outbreaks in horses (RODRIGUES et al., 2005). Farmers of the Pantanal region report that outbreaks in horses are usually preceded by outbreaks in capybaras (SILVA et al., 2002). A similar situation was reported by the 
Table 1 - Number of positive animals by municipalities with positive percentage.

\begin{tabular}{lccc}
\hline Municipalities & Proportional stratified samples & Positive animals on PCR & Percentage of positive animals \\
\hline Chaves & $127^{*}$ & $14^{* *}$ & $11 \%$ \\
Santa Cruz & 24 & 6 & $25 \%$ \\
Cachoeira & 12 & 0 & 0 \\
Salvaterra & 5 & 0 & 0 \\
Soure & 75 & 0 & 0 \\
Total & 243 & 20 & $8,23 \%$ \\
\hline
\end{tabular}

${ }^{*}$ Regarding the municipality of Chaves, 57 samples were collected during the outbreak 2 , in the rainy season, and 70 samples were collected during the epidemiological survey, in the dry season. ${ }^{* *}$ All positive samples in municipality of Chaves were collected during the outbreak 2.

farmers in the present study, with observation of neurological signs and mortality in capybaras from July to December.

The possibility that wild animals, such as capybaras, coatis, and small wild rodents, act as a source of infection in trypanosomiasis cases in Marajó Island is very plausible. Farmers related that before the prohibition of capybara hunt, the population of this big rodent was controlled and they did not observe the disease in horses or capybaras.

The neurological clinical signs observed in the horses of this study are similar to those described by RODRIGUES et al. $(2005 ; 2009)$ in the state of Rio Grande do Sul, Brazil. Ventral edema and progressive weight loss were also observed in these animals, as described in other trypanosomiasis outbreaks in horses (MARQUES et al., 2000; HERRERA et al., 2004; RODRIGUES et al., 2009). Necropsy of the second horse revealed atrophy of large muscle masses, especially from the pelvic limbs, and enlarged spleen with protrusion of the white pulp. Microscopically, there was lymphoid hyperplasia in the spleen and systemic hemosiderosis. These findings are similar to those described by HERRERA et al. (2004) and RODRIGUES et al. (2009). Microscopic lesions observed in the CNS were characterized by diffuse lymphoplasmacytic encephalitis with Mott cells, similarly to the findings described by RODRIGUES et al. $(2005,2009)$. Mott cells are modified plasma cells with a small, peripheral nucleus and cytoplasm filled with Russell bodies. Presence of these cells in the perivascular infiltrates in the central nervous system in cases of trypanosomiasis are considered typical features of the infection and may be involved in immune-mediated vasculitis associated with this group of diseases (POLTERA et al., 1977).

These lesions have also been observed in infection by $\boldsymbol{T}$. evansi in bovines, which developed the neurological form of the disease (TUNTASUVAN et al., 2000). Immunohistochemistry revealed trypomastigote specimens labeled by anti-T. evansi antibody in sections of CNS. This technique has been used in cases of natural infection by $\boldsymbol{T}$. evansi, allowing for an association of lesions with the presence of the parasite (TUNTASUVAN et al., 2000; RODRIGUES et al., 2009).

The first and second outbreaks described in this study exhibited morbidity rates of $37.97 \%$ and $30.07 \%$ and mortality rates of $27.21 \%$ and $26.97 \%$, respectively. These values are similar to those reported by RODRIGUES et al. (2005) in the state of Rio Grande do Sul, Brazil. SILVA et al. (1995a) reported a mortality rate of 51\% in Pantanal, which was much higher than the one described in this study. Pantanal is considered an endemic zone for this disease. However, with the establishment of preventive measures, using chemoprophylaxis and control of vectors with pour on insecticides, and although quinapyramine is also used for prophylactic purpose, it has been possible to decrease the number of clinical cases of tripanosomiasis (SILVA et al., 2002). In Marajó Island, which has epidemiological conditions for the occurrence of the disease similar to those observed in Pantanal, no adequate control or prophylactic measures have been implemented. The Marajó Island, in its eastern part, suffers during rainy periods, the compression of the Amazon waters, and the rivers of the region, which are natural spillways, are not able to drain all this volume water, flooding the fields (LISBOA, 2012). Similarly, the Pantanal presents hot and humid climate with flooded regions favorable to the appearance of the vectors responsible for the transmission of T. evansi, linked to the presence of natural reservoirs, which are predisposing factors for the occurrence infection (SILVA et al., 1996).

Molecular testing by PCR detected the presence of $\boldsymbol{T}$. evansi DNA in 20 of $243(8,23 \%)$ horses investigated. CLAES et al. (2004) claims that the specific primer for $\boldsymbol{T}$. evansi used in this study, ROTAT 1.2, is the most sensitive for detection of 
T. evansi since it amplifies a segment of a gene that codes for a surface glycoprotein (VSG) which is specific for this agent. Furthermore, its use is recommended by those authors for the detection of dyskinetoplast strains of T. evansi; according to VENTURA et al. (2000), Brazilian strains do not exhibit kinetoplast, a structure that corresponds with the DNA (kDNA) of their unique mitochondrion. Low parasitemia during sample collection could explain absence of $\boldsymbol{T}$. evansi DNA in samples with a negative PCR result. RAMÍREZ-IGLESIAS et al. (2011) compare diagnostic techniques in rabbits experimentally infected with $\boldsymbol{T}$. evansi, and during the phases of low parasitemia, the highest diagnostic was by PCR technique $(93,8 \%)$, recommending the use of PCR in epidemiological studies. In this case, the quantitative of $\boldsymbol{T}$. evansi in the rabbits infected was known, different from the naturally occurring field cases where parasitemia are often low and sporadic. Even though PCR is a very sensitive method, it can yield false-negative results in cases of low parasitemia (OIE, 2010).

JANSEN (1941) reported the presence of T. evansi infection in horses $(20,7 \%)$ in the municipalities of Muaná, Soure, and Cachoeira do Arari. In the present study, in spite of reports of occurrence of vectors, reservoirs, and favorable climatic conditions for $\boldsymbol{T}$. evansi infection in the municipalities of Soure and Cachoeira do Arari, farm owners did not report the disease in the last years, and neither the diagnostic techniques detected positive horses. Possibly, the increasing of human occupation in the regions of Soure and Cachoeira do Arari may have modified the environment and the relationship between hosts and vectors, with the possible reduction of the same. Unlike what occurs in the area of Chaves and Santa Cruz do Arari, where human occupation it is not so intense by the difficulty of access, which possibly holds these regions in conditions closer to those reported by Jansen in 1941.

The last report of the disease caused by T. evansi in Marajó Island, Pará, occurred in 1941 by Jansen when he observed the infection in horses. Since then, there was a gap between the study of Jansen and the reemergence of the disease in Marajó as described in this study.

\section{CONCLUSION}

The Trypanosoma evansi infection occurs in the municipality of Chaves and Santa Cruz do Arari, with the outbreaks occurred in horses in Chaves. The first and second outbreaks described in this study exhibited morbidity rates of $37.97 \%$ and $30.07 \%$, mortality rates of $27.21 \%$ and $26.97 \%$, respectively. The PCR was effective to detect natural infection by $\boldsymbol{T}$. evansi in horses examined (8, $23 \%$ ). The study showed that the disease has a major impact on the horse breeding, as well as for livestock; and therefore, to the economy in municipalities of microregion of Arari, Marajó island. Marajó Island has the largest population of horses of Pará, and the use of these horses is extremely important in extensive management of cattle and buffaloes. In this regard, an immunosuppressive disease, like tripanosomiasis, can dramatically compromise the local economy. The disease caused by $\boldsymbol{T}$. evansi should be considered in the differential diagnosis of other neurological syndromes in horses, particularly on the Island of Marajó, Pará.

\section{ACKNOWLEDGEMENTS}

We thanks to the farm owners on Marajo Island for the support during the visits on the farms.

\section{REFERENCES}

ABEER, A. A.; SHAYMAA, I.S. Clinicopathological and cytological studies on naturally infected camels and experimentally infected rats with Trypanosoma evansi. World Applied Sciences Journal, v.14, p.42-50, 2011. Available from: <http://www.idosi. org/wasj/wasj14(1)11/6.pdf>. Accessed: July 15, 2013.

CAMARGO, R. E. et al. Isolation of two antigens from Trypanosoma evansi that are partially responsible for its crossreactivity with Trypanosoma vivax. Veterinary Parasitology, v.123, p.67-81, 2004. Available from: <http://www.sciencedirect. com/science/article/pii/S0304401704002365>. Accessed: july. 16, 2013. doi: 10.2016/j.vetpar.2004.01.022.

CARREIRA, J.C. Sanguessugas podem transmitir o mal das cadeiras, doença de eqüinos que tem grande importância econômica no Brasil. 2005. Online. Available from: <http:// www.agencia.fiocruz.br/sanguessugas-podem-transmitir-o-malde-cadeiras-doença-de-eqüinos-que-tem-grande-importânciaeconômica-no-brasil>. Accessed: Dec. 15, 2013.

CLAES, F. et al. Variable surface Glycoprotein RoTat 1.2 PCR as a specific diagnostic tool for the detection of Trypanosoma evansi infections. Kinetoplastid Biol and Dis, v.3, p.3-9, 2004. Available from: <https://kinetoplastids.biomedcentral.com/ articles/10.1186/1475-9292-3-3>. Accessed: nov. 10, 2013. doi: $10-1186 / 1475-9292-3-3$.

HERRERA, H.M. et al. Enzootiology of Trypanosoma evansi in Pantanal, Brazil. Veterinary Parasitology, v.125, p.263275, 2004. Available from: <http://www.ncbi.nlm.nih.gov/ pubmed/15482883>. Accessed: dec. 10, 2012. doi: 10.1016/j. vetpar.2004.07.013.

JANSEN, G. Contribuição ao estudo do mal de cadeiras na Ilha de Marajó. Memórias do Instituto Oswaldo Cruz, v.6, p.145-163, 
1941. Available from: $<$ http://www.scielo.br/scielo.php?script=sci arttext\&pid=S0074-02761941000300010>. Accessed: july. 15, 2012. doi: 10.1590/s00074-02761941000300010>.

LISBOA, P.L.B. A terra dos Aruã. Uma história ecológica do Marajó. Belém: Museu Paraense Emílio Goeldi, 2012. 482p.

ORGANIZAÇÃO MUNDIAL DE SAUDE ANIMAL (OIE) NB: Version adopted by the World Assembly of Delegates of the OIE in May 2010. OIE Terrestrial Manual 2010. Online. Available from: <http://www.oie.int/fileadmin/Home/eng/ Health_standards/tahm/2.01.17_TRYPANO.pdf $>$. Accessed: May $1 \overline{4}, 2012$.

POLTERA A.A. et al. Pathological aspects of human African trypanosomiasis (HAT) in Uganda: A post-mortem survey of fourteen cases. Virchows Arch, v.373, p.249-265, 1977. Available from: <http://www.ncbi.nlm.nih.gov/pubmed/140506>. Accessed: May. 14, 2012. doi: 10.1007/bf00432240.

RAMÍREZ-IGLESIAS, J.R. et al. Trypanosoma evansi: A comparative study of four diagnostic techniques for trypanosomosis using rabbit as an experimental model. Experimental Parasitology, v.128, p.91-96, 2011. Available from: <http://www. ncbi.nlm.nih.gov/pubmed/21320490>. Accessed: nov. 10, 2013. doi: 10.1016/j.exppara.2011.02.010.

REID, S.A. Trypanosoma evansi control and containment in Australasia. Trends Parasitology, v.18, p. 219-224, 2002. Available from: <http://www.sciencedirect.com/science/article/ pii/S147149220202250X>. Accessed: dec. 10,2012. doi: 10.1016/ s1471-4922(02) 02250-X.

RODRIGUES, A. et al. Neuropathology of naturally occurring Trypanosoma evansi. Infection of horses. Veterinary Pathology, v.46, p.251-258, 2009. Available from: <http://www.ncbi.nlm.nih. gov/pubmed/19261636>. Accessed: dec. 10, 2012. doi: 10.1354/ vp.46-2-251.

RODRIGUES, A. et al. Surtos de tripanossomíase por Trypanosoma evansi em eqüinos do Rio Grande do Sul: aspectos epidemiológicos, clínicos, hematológicos e patológicos. Pesquisa Veterinária Brasileira, v.25, p.239-249, 2005. Available from: $<$ http://www.scielo.br/scielo.php?script=sci_arttext\&pid=S0100736X2005000400010>. Accessed: dec. 10, 2012. Doi: 10.1590/ S0100-736X2005000400010.

SILVA, R.A.M.S. Pathogenesis of Trypanosoma evansi infection in dogs and horses: hematological and clinical aspects. Ciência Rural, v.25, p.233-238, 1995b. Available from: $\quad<$ http://www.scielo.br/scielo.php?script=sci_arttext\&pid $=$ S0103-84781995000200010 $>$. Accessed: May. 13, 2012. Doi: $10.1590 / \mathrm{S} 0103-84781995000200010$.

SILVA, R.A.M.S. et al. Trypanosoma evansi e Trypanosoma vivax - Biologia diagnóstico e controle, EMBRAPA. Online. Available from: <http://www.cpap.embrapa.br/publicacoes/online/Livro015. pdf, 2002>. Accessed: May 13, 2012.

SILVA, R.A.M.S. et al. Outbreak of trypanosomosis due to Trypanosoma evansi in horses of Pantanal Mato-grossense, Brazil. Veterinary Parasitology, v.60, p.167-171, 1995a. Available from: $\quad<\mathrm{http} / / / \mathrm{www}$.sciencedirect.com/science/ article/pii/0304401794007574>. Accessed: May 13, 2012. doi:10.1016/0304-4017(94)00757-4.

TUNTASUVAN, D. et al. Detection of Trypanosoma evansi in brains of the naturally infected hog deer by immunohistochemistry. Veterinary Parasitology, v.87, p.223230, 2000. Available from: <http://www.sciencedirect.com/ science/article/pii/S0304401799001648>. Accessed: May 13, 2012. doi:10.1016/S0304-4017(99)00164-8.

VENTURA, R.M. Molecular and morphological studies of Brazilian Trypanosoma evansi stocks: the total absence of kDNA in trypanosomes from both laboratory stocks and naturally infected domestic and wild mammals. Journal of Parasitology, v.86, p.1289-1298, 2000. Available from: $<$ http://www.journalofparasitology.org/doi/abs/10.1645/002 23395\%282000\%29086\%5B1289\%3AMAMSOB\%5D2.0.C O\%3B2?journalCode=para $>$. Accessed: May. 13, 2012. doi: 10.1645/0022-3395(2000)086[1289:MAMSOB]2.0.CO;2. 